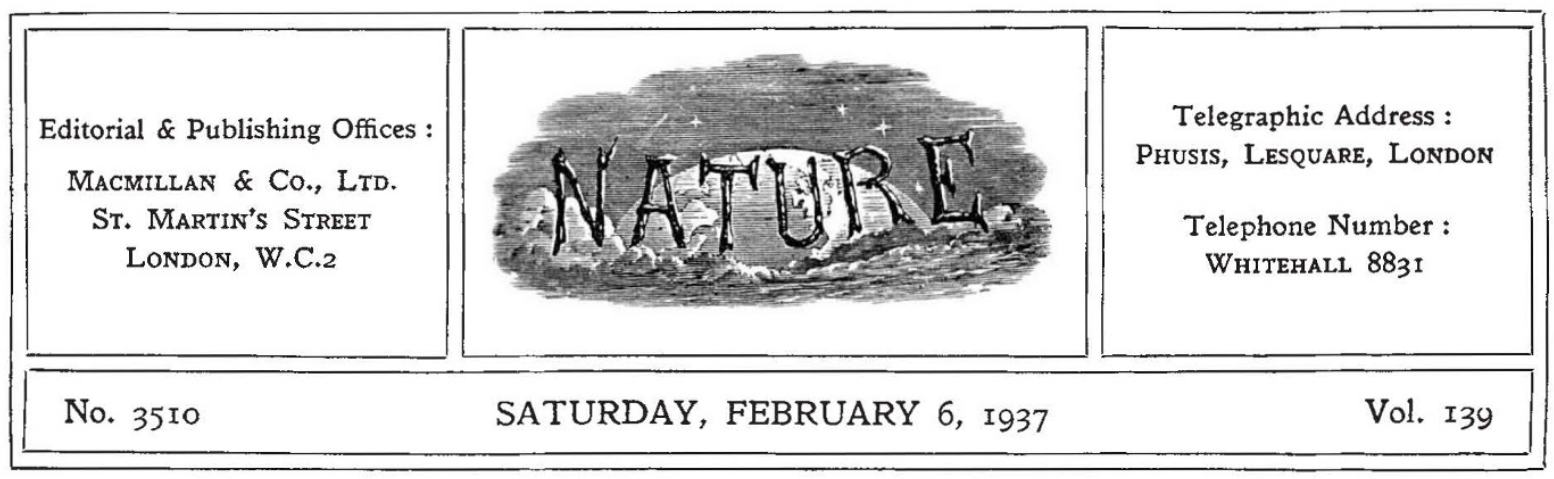

\title{
Location of Industries
}

$\mathrm{T}^{\mathrm{H}}$ HE attention which, in the recent reports of the Commissioners for the Special Areas, has been directed to the attraction to, and the stimulation of, industry within those areas is only a particular example of the increasing interest which is being taken in the location of industry in Great Britain. The importance of rehabilitating the depressed areas of the country, whether those specially scheduled in the Special Areas Act or those other 'black spots' of the country such as the weaving and coal-mining areas of Lancashire, where unemployment is at least as great as in some of the Special Areas, and the signs of revival even less, is only one of many considerations bringing this matter to the front.

In his third report, the Commissioner of the Special Areas in England and Wales, while repudiating the idea of direct State control of the location of industry, advocated some measure of indirect control in the proscription of the location of industry in the London area, except for very definite and special reasons. Although this suggestion was intended to benefit the Special Areas, the argument rested at least as much on the relative vulnerability of London and the home counties, and the latter factor is obviously one of which increasing account must be taken unless we succeed in evolving a much more promising international order.

At the same time, the location of industry, like the planning of cities and towns, assumes greater importance from the increasing danger of destroying by indiscriminate building the amenities and beauty of our countryside. Ribbon-building has already done irreparable damage on both highways and coast, and unless effective control is exercised in these matters, as in questions of atmospheric or riparian pollution, little may be left to us of the rich heritage of rural England which was ours at the commencement of this century. Finally, transport considerations themselves are enforcing the consideration of the location of industry, so as to avoid the economic and social wastefulness and strain upon health involved in carrying immense numbers of tired people long distances to and from their work in overcrowded vehicles occupied only for a small fraction of the day.

Town planning, the location of industry, national health and defence, and the preservation of rural England, are in fact essentially different facets of one problem calling for long-range statesmanship and resolute scientific investigation. The strong criticism which the Government proposal to build an aircraft factory at White Waltham, near Maidenhead, received in the House of Commons, and the indignation which it aroused elsewhere, was due as much to the Government's countenancing Departmental violation of this principle as to the threat to the amenities of the Thames valley and the disregard of the claims of the Special Areas and the Commissioner's recommendations. Happily, the volume of protest, from all parties, was such that on January 26 Mr. Baldwin announced that the scheme had been abandoned, and that a new site will be sought in Lancashire.

It is not the least of the services performed by Mr. Malcolm Stewart, until recently Commissioner for the Special Areas, that he has so repeatedly emphasized the necessity for considering these areas as a problem of economic and social redevelopment on a very wide basis, calling for a definite national policy. The point is further stressed in an admirable broadsheet entitled "The 
Location of Industry" which has just been issued by Political and Economic Planning (P E P). It is not merely that we are tending to consider the wider economic and social costs of different industrial policies and to realize the heavy offset to prosperity in the Midlands and South represented by wretched and paralysed groups of communities in Wales and the North. Increasingly we are coming to appreciate that there are definite opportunities of reconstruction and replanning in the present situation, which, if wisely used, may involve almost as great benefit to the whole community as to any special section for whose benefit they are immediately initiated.

The Government itself has repeatedly emphasized the experimental character of the Special Areas Act. From the experience of the selected areas was to be crystallized all those methods which could be adopted in other areas suffering from heavy unemployment. The Special Areas were essentially a large-scale social experiment. On this point the valuable study "Re-adjustment in Lancashire"*, prepared by members of the Economics Research Section of the University of Manchester, bases one of its most powerful arguments for inclusion of the weaving districts of Lancashire within the Act. The present limits of the Act are arbitrary and convenient, rather than based rationally on economic or geographical facts, but can be justified for the purpose of an experiment so long as the experiment is representative. "Re-adjustment in Lancashire", however, seizes upon the point that the four areas so far selected are not representative of conditions in the weaving districts, because, unlike all the Special Areas, the rate of unemployment there is higher for women than for men.

The main importance of this most recent survey by the University of Manchester lies in the analysis and exposure of conditions in the weaving district. The case for including this area to obtain data for conditions not yet covered by districts already scheduled is presented with all the thoroughness, lucidity and impartiality which we have learnt to associate with the work of this Economics Research Section. There are, however, other matters bearing on the location of industry in Lancashire to which the investigation also directs attention. One of its principal suggestions is in regard to the establishment of a trading estate and the provision of capital at low rates to provide a favourable environment for local industrial enterprise, par-

\footnotetext{
* Re-adjustment in Lancashire. By Members of the Economics Research Section, University of Manchester. Pp. vii + 137. (Manchester : Manchester University Press, 1936.) 4s. $6 d$. net.
}

ticularly with the view of attracting industries employing women. Special attention is directed to the possibility of the district becoming a large and growing centre for the clothing trades.

Former strictures upon blind-alley work, casual employment and the exploitation of young persons as well as of the unemployed in Lancashire generally are repeated, and the social evils which flow from an industry continually discarding its workers as they become older are still far from receiving the attention they demand. The possibilities and limitations of road construction in the area in regard to unemployment, of cleaning up the face of the country by demolishing derelict mills and similar measures are also considered, and the investigation makes it clear how little the rearmament programme can contribute to the solution of Lancashire's most intractable problems. This sober but impressive marshalling of the facts should at least assist to secure fair consideration for an area much greater in size than one or two of the Special Areas, and no less deserving.

If the investigation we have just discussed reveals the limitations of the present Special Areas Act, and the necessity for fresh schedules or for the rapid extension of the experience gained to other 'black spots' of unemployment, the need is emphasized for a national policy and above all for the consideration of the location of industry by creative minds free from prejudice and competent to take into account all the many aspects of national and social policy and well-being involved. The case for a national policy is the more imperative since its realization in practice depends upon the utilization of the opportunities of reconstruction and development afforded not merely in the Special Areas but also in special emergencies.

The most cursory glance at this problem should indicate how interlocked is this whole question of the location of industry and national reconstruction, and the importance of a central authority powerful and unbiased enough to secure action on behalf of the national and not sectional interests. The comparison cited in the P E P Broadsheet between the treatment of the Special Areas and the subsidizing of the sugar beet industry alone illustrates how disproportionate is our present policy, and the need for some wider co-ordination and vision. The wisdom of subsidizing the sugar beet industry has been attacked on scientific grounds, but however great the intrinsic merits of the sugar beet subsidy, it is difficult to defend the subsidizing in this way of a population of 
about half a million, in comparison with the treatment of a population more than eight times as great in the Special Areas and in considerably more desperate straits. Drift from the depressed areas will only be checked as it is made worth while for a sufficient proportion of the natural leaders who are thrown up in each area to stay in it happily, doing constructive work instead of becoming narrowed and embittered, and quitting it in favour of somewhere more attractive.

The Special Areas are merely a particularly acute and painful example of the growing disequilibrium and sapping of vitality created by the excessive expansion of the metropolis. Moreover, years of mismanagement and neglect rather than sudden and unforeseeable misfortune are responsible for tragedies such as those of the coal-mining, cotton, fishing and sections of the agricultural industries, together with the areas mainly dependent upon them. The conclusion is inescapable that in future all major adjustments of policy should be examined not only with reference to their effects on the industry or other activity concerned but also with reference to their effects on the balance of national development. A constructivelyminded Government, ready at the first signs of trouble to invest money in development work such as trading estates and new or improved communica. tions, to bring in fresh industries or marketing measures and research to stimulate backward industries, could probably have salvaged many million pounds of expenditure in the last dozen years which has led the industry or area concerned no nearer a permanent self-supporting basis. "Re-adjustment in Lancashire" and the P E P Broadsheet are yet further reminders of the part which scientific investigation must play in the development of economic, social and industrial poliey, and of the dire peril which attends neglect or failure to secure a more balanced national development and reconstruction in which internal strains between different areas and industries are minimized and a reasonable measure of social justice maintained.

\section{The Science of English History}

\section{Roman Britain and the English Settlements}

By Prof. R. G. Collingwood and J. N. L. Myres. (The Oxford History of England.) Pp. xxvi +515 . (Oxford: Clarendon Press; London: Oxford University Press, 1936.) 12s. $6 d$. net.

THIS volume on Roman Britain and the English settlements is the first (though not the first to be published) in a series of fourteen covering the history of England, edited by Prof. G. N. Clark. The full-dress treatment of the theme commences with Cæsar's invasion, but this is preceded by a thirty-page introduction in which the geographical background and the prehistory of Britain are sketched in. Prof. Collingwood's contribution carries us through the Roman period into the fifth century; there Mr. J. N. L. Myres picks up the story, discussing that same century from the Anglo-Saxon point of view, and then the general problems of the English Settlement.

In 1910 Sir Charles Oman produced his very successful "History of England before the Norman Conquest". Though the new History is on a slightly larger scale, the two works are closely comparable, and it is interesting to see how they differ. Confining ourselves for the moment to the Roman period, Oman's survey is mainly military and political, based on documentary evidence (including coins and inscriptions). Collingwood, on the other hand, devotes more than one third of his pages to economic history and cognate studies. It is archæology that has made this possible in a period in many ways so ill-documented. The remarkable progress made by the science of the spade in recent years, and especially since the Great War, is familiar to all ; a single contrast will bring it home. Some seventeen years work at Silchester, completed in 1906, laid bare the plan of a Romano-British town, but nothing else; on the other hand, three years work at Verulamium in 1932-34 revealed the history of an experiment in urbanization extending over nearly half a millennium, its growth, changes, vicissitudes and decay. On the military side, again, the postWar labours of field archæologists on the Roman Wall, at Richborough, Caerleon, Segontium and many other sites have given a new vitality and precision to the history of the army. The vigour of the development of archæology is also shown by the extent to which the natural sciences are drawn into the orbit of its research, and by the success with which novel techniques such as air photography are being exploited. All such aspects of field work are reflected in this volume, and help to mould its character. 